\title{
Fra resultatkontrakt til mål- og resultatplan: Ny inspiration til realiseringen af resultatstyringens potentialer
}

\author{
Marie-Louise Frølich Brødsgaard \\ stud.scient.pol, Institut for Statskundskab, Københavns Universitet \\ Mads Bøge Kristiansen \\ ph.d., post.doc., Institut for Statskundskab, Københavns Universitet
}

Siden introduktionen af resultatkontrakter i 19911992 har Finansministeriet med jævne mellemrum lanceret publikationer indeholdende opdateredeanbefalinger til designet og implementeringen af mål- og resultatstyring. Senest har Finansministeriet i efteråret 2014 præsenteret en ny model for mål- og resultatstyring i staten, der vakte redaktionens nysgerrighed. Vi satte derfor kontorchef Stig Henneberg og fuldmægtig Nanna Skriver Dall fra Finansministeriets Center for udgiftspolitik og modernisering stævne en fredag morgen i september 2014. Vi ønskede bl.a. at blive klogere på, hvorfor Finansministeriet vurderer, at der er behov for en revision af det eksisterende koncept, hvad den nye model indeholder samt, hvorfor den nye model forventes at kunne løse nogle af de problemer, det statslige mål- og resultatstyringskoncept hævdes at være præget af?

\section{Hvorfor har I andret mål- og resultatstyringskonceptet?}

Vi har haft resultatkontrakter i staten i efterhånden mange år, men når vi talte med dem, der i praksis anvender resultatkontrakterne i ministerierne, og når vi læste det, forskere skrev om resultatkontrakterne som styringskoncept, så tegnede der sig et billede af, at resultatkontraktkonceptet efterhånden var sandet en smule til.
Problemet var bl.a., at det var lidt uklart, om resultatkontrakterne rent faktisk blev brugt som styringsværktøjer, eller om det i højere grad var noget, man lavede, fordi det skulle man nu engang - og uden at de topchefer, der gerne skulle anvende værktøjet, rent faktisk brugte det. En del af baggrunden for problemet var, at der havde været en tendens til målinflation i resultatkontrakterne. Man forsøgte fra nogle institutioners side måske at dække hele sin opgaveportefølje i kontrakterne; men hvis der ikke bliver prioriteret imellem målene, så ender man i en situation, hvor det grundlæggende er uklart, hvad institutionen faktisk styrer efter. Samtidig var der en tendens til, at resultatkontrakterne skulle tjene for mange formål på én gang og derfor ikke blev fokuseret tilstrækkeligt om institutionernes strategiske retning og kerneopgaverne.

Det var baggrunden for, at vi gik i gang med en analyse af resultatkontrakterne. Vi har lavet kvantitative optællinger af mål- og resultatkrav i resultatkontrakterne, og vi har gennemført en række interviews med bl.a. praktikere, topchefer - både departementschefer og styrelsesdirektører - , forskere og konsulenter. På baggrund af det arbejde har vi i et samarbejde mellem Finansministeriets departement og Moderniseringsstyrelsen lanceret den nye model, der introducerer begrebet „mål- og resultatplaner", som resultatkontrakternes afløser. Modellen skal tjene som inspiration til videreudviklingen af mål- og resultatstyringen og er ikke normerende. 
Hvad er de vesentligste forskelle i forhold til det tidligere kontraktstyringskoncept?

En central forskel er, at mål- og resultatplanerne opererer med væsentligt færre og klarere mål. Noget af det, vi observerede i gennemgangen af resultatkontrakterne, var, at kontrakterne, som sagt, tjente mange formål på én gang. $\mathrm{Nu}$ lægges der op til et fokus på kerneopgaverne og styrelsens strategiske sigte. Samtidig indebærer modellen, at det typisk ikke vil være alle kerneopgaver i en institution, som indgår i mål- og resultatplanen. Der er en anbefaling om, at en mål- og resultatplan maksimalt indeholder 5-10 mål. Det er primært mål, der knytter sig til institutionens strategisk prioriterede kerneopgaver, idet et begrænset antal af målene - vi har sagt 1-3- dog kan vedrøre styrelsens interne administration.

Der er også gjort et forsøg på at blive klarere på de forskellige slags mål. I den nye model er der en sondring mellem det, vi kalder drifts- og policylignende kerneopgaver. For driftsopgaver kan der i vid udstrækning opstilles objektive, kvantificerbare mål. For policyopgaverne vil det også, i det omfang det kan lade sig gøre, være relevant at søge at lave objektive, kvantificerbare mål, men samtidig må man erkende, at målformulering og opfølgning på mål ofte vil have en mere skønsmæssig og kvalitativ karakter.

Så prøver vi også med den nye model at få gjort det tydeligere, at mål- og resultatplaner er forankret på toplederniveau hele vejen igennem fra udarbejdelse til opfølgning. Det er vigtigt, at det ikke bliver et dokument, der bare lever sit eget liv nede i institutionerne, men at det er noget, som topchefer i departementer og styrelser rent faktisk bruger. Mål- og resultatplanen skulle gerne være et reelt omdrejningspunkt for dialogen mellem departementschef og styrelsesdirektør. Det er bl.a. også baggrunden for, at vi har udarbejdet en pjece, som er meget kort og "to the point". Topchefer har travlt, og det nye materiale er søgt tilpasset den kontekst.

Derudover er der en understregning af, at det er vigtigt - det burde måske sige sig selv - at mål- og resultatplaner foreligger, inden året starter. Det skyldes, at der har været en tendens til, at resultatkontrakter i nogle tilfælde har været noget, der er blevet lavet i løbet af året. Men hvis det også er processen fremadrettet, så kan målog resultatplanerne ikke blive et reelt grundlag for styring og for en prioritering af, hvad den konkrete institution skal tage sig af det næste år.

Samtidig lægges der i den nye model vægt på, at målog resultatstyring for den konkrete styrelse er noget, som departement og styrelse skal arbejde med i fællesskab. I visse tilfælde har der måske været en tendens til, at styrelsen selv har lavet sin resultatkontrakt, og hvorefter den er blevet sendt over i departementet, som mere eller mindre har taget kontrakten til efterretning - og det er selvfølgelig ikke hensigten. Mål- og resultatplanen er derfor et dokument, som er forankret på begge sider af bordet, og hvor departementet samtidig reelt løfter sin opgave med at "styre sin styrelse“.

Vi har herudover søgt at være relativt skarpe på formen for mål- og resultatplanerne. De tre elementer i planerne er dels det, vi kalder et flerårigt strategisk målbillede, som beskriver styrelsens vigtigste opgaver og dens raison d'être, dels de 5-10 årlige mål, og endelig er det afgørende med en struktureret og løbende opfølgning.

\section{I pjecen anbefaler I, at man kan lave 1-3 mål for den interne administration, hvad er baggrunden for det?}

Idéen er, at selvom målene primært omhandler den eksternt rettede kerneopgave, så kan der for enhver institution eller styrelse være nogle mål vedrørende styrelsens interne administration og daglige drift, som kan være så vigtige, at de fortjener at være blandt de 5-10 mål, der strategisk styres efter.

Det kan fx være mål, der handler om at sikre, at man har en effektiv drift eller en god og sund økonomi. Det kan være mål om, at man fx er præcis i sine prognoser, hvilket er en central del i forhold til økonomistyring og opfølgning på budgetloven. Det kan også være mål for HR, fx et mål om at reducere sygefravær.

I og med at vi taler om 1-3, så indikerer vi også, at det vil være meget individuelt fra styrelse til styrelse, i hvilket omfang det er relevant at operere med mål, der har denne her karakter.

\section{Har I prasenteret mål- og resultatplanen for nogle af de topchefer, I talte med indledningsvist?}

Det har vi gjort løbende. Vi har i det hele taget været optagede af, at det nye materiale blev til på en måde, hvor vi inddrog relevante ressourcepersoner og særligt dem, der skulle bruge det efterfølgende.

En del af vores analyse har vist, at noget af det, der nogle gange ikke har fungeret ved de hidtidige resultatkontrakter, har været fraværet af ejerskab. For at topchefer kan tage den nye model til sig, skal de synes, at det fungerer - at det understøtter deres arbejde. Derfor har vi igennem hele analyseprocessen været opmærksomme på at tale med de relevante folk, forstå, hvordan de ser verden, og teste nogle forskellige udkast på dem.

$\mathrm{Nu}$ er den nye model så offentliggjort og ligger på Moderniseringsstyrelsens hjemmeside, og den har bl.a. været præsenteret for departementschefniveauet. Vi har samlet set fået rigtig god respons. Alle deler analysen af, 
at det her er utrolig vigtigt. Alle deler også analysen af, at der var brug for en revitalisering af mål- og resultatstyringsværktøjet, og vi tror, der er bred enighed om, at det her kan være et meget godt svar på de behov, der findes.

Samtidig skal man huske, at den nye model er tænkt som inspiration. I vores samtaler med dem, der anvender mål- og resultatstyring til daglig, har vi fundet ud af, at der er flere ministerier, der allerede er rigtig godt på vej, og at der kan være stor forskel på, hvad det er, der kunne komme til at fungere rigtig godt på de enkelte ministerområder. I tråd med at sikre ejerskab har vi ønsket at give inspiration til, hvordan man kan videreudvikle sin mål- og resultatstyring, og hvad der kunne ligge i god strategisk styring. Samtidig er der frihed til, at institutionerne kan indrette styringen, som det bedst passer hos dem. Det er også baggrunden for, at modellen ikke er mere konkret, end den er, men i højere grad bygger på nogle relevante styringsprincipper. Det er netop, fordi der har været en erkendelse af, at man ikke meningsfuldt kan lave en specifik „one size fits all“-model.

\section{Nu har I så lanceret pjecen og inspirationsmaterialet, men hvordan kan I understøtte, at det så også bliver implementeret og taget $i$ brug $i$ de enkelte ministerier?}

Det er et godt spørgsmål, og der er selvfølgelig forskellige ting, vi kan gøre fra Finansministeriets side. I sidste ende afhænger modellens succes dog af, hvorvidt ministerierne tager den til sig og har lyst til at bruge principperne derude; men vi har fx lavet et inspirationsmateriale, som i modsætning til pjecen er et noget længere dokument. I inspirationsmaterialet er der nogle mere grundige overvejelser over, hvilke mål som er relevante i forskellige situationer, og der er nogle konkrete cases fra virkelige institutioner med inspiration til, hvordan man kan gøre i praksis. Inspirationsmaterialet er tænkt som et interaktivt produkt, der løbende bliver udviklet. Det kommer til at ligge på Moderniseringsstyrelsens hjemmeside, og efterhånden, som der kommer nye cases ind, vil det blive udbygget. Håbet er, at det kan blive en form for børs for gode idéer og gode erfaringer.

Så vil vi, og særligt Moderniseringsstyrelsen, også løbende i forskellige fora, hvor ministerier og styrelser mødes, tage initiativ til, at mål- og resultatstyring kommer på dagsordenen. Vi vil samtidig sikre, at der på et tidspunkt bliver gjort status - også på højere niveau - for arbejdet med mål- og resultatstyring i staten, bl.a. på baggrund af lanceringen af den nye model.

Tanken er egentlig at gå i dialog, fx ved at Moderniseringsstyrelsen afholder en række informationsmøder, hvor der er mulighed for at stille spørgsmål til, hvordan der kan arbejdes videre med mål- og resultatstyring. Vi tror også, at det kunne være vejen frem at skabe en øget fælles læring.

\section{Hvilke udfordringer ser I for implementeringen?}

Det vil til stadighed være en udfordring at sikre, at sådan nogle dokumenter som mål- og resultatplanen får den rigtige form, så de reelt understøtter mål- og resultatstyring og dialog. Altså sikre, at planerne ikke bare bliver et bureaukratisk instrument, som man har, fordi det skal man nu engang have, eller fordi Finansministeriet siger, at det er klogt; men at det er noget, institutionerne reelt tager til sig. Det handler bl.a. om at få formuleret nogle mål, som styringsmæssigt er meningsfulde, at man ikke falder for fristelsen til at lave alt for mange mål, og at man ikke begynder at definere mål ud fra „uvedkommende“ hensyn, $\mathrm{fx}$ at sikre sig at hele institutionens portefølje er fuldt dækket i mål- og resultatplanen, eller at mange forskellige eksterne interessenter alle skal kunne se sig selv i planen.

Der kan have været mange årsager til, at man nogle steder endte i en situation, hvor man havde utrolig mange mål. Og det er i sidste ende et ledelsesansvar at sikre, at man ikke bevæger sig derhen.

Så er det også en udfordring at sikre, at strategibilledet er rigtigt, at målene er rigtige, og at sikre, at der rent faktisk bliver fulgt op. At sikre, at mål- og resultatplanerne ikke bliver ceremonielle dokumenter, man taler om en gang om året, og så bliver de puttet i skrivebordsskuffen, men at man i stedet får integreret planerne i den løbende styringsdialog imellem fx en departementschef og en styrelsesdirektør. Det kan eksempelvis ske i koncernledelsesmøder i en form for „multilateral proces“, hvor repræsentanterne for alle ministerområdets institutioner sidder omkring bordet. Det kan også ske i en bilateral proces, hvor man som departementschef sikrer sig, at man med jævne mellemrum har dialog og kontakt med sine styrelsesdirektører. Er vi on track? Hvordan skal dokumentet se ud næste år? Hvordan får vi fulgt op? Hvad gik godt? Hvad gik mindre godt? Det er en central udfordring, og på den måde kan man sige, er udfordringen jo den samme, som den altid har været med mål- og resultatstyring og med de gamle resultatkontrakter: At sikre, at det bliver et relevant styringsdokument.

\section{I modellen er der meget fokus på toplederen, både $i$ formuleringsprocessen og $i$ opfølgningsprocessen. De er jo nogle travle mennesker, sà hvordan kan man sikre, at de fokuserer på det her?}

Vi har ikke en idé om, at mål- og resultatstyring kun er relevant at beskæftige sig med for topledere. Vi tror egentlig, at det er ret vigtigt at have med i billedet, at 
det jo er medarbejderne, der skal levere resultaterne. Det er medarbejderne, der skal indfri målene. Når vi taler meget om topledelsesinddragelse, så er det, fordi vores interviews har vist, at det måske er der, det har haltet en smule. Der har måske været en udmærket dialog på kontorniveau, og det kan jo være fint, men det er klart, at det ikke er tilstrækkeligt, hvis mål- og resultatplanerne virkelig skal sætte den strategiske retning og bidrage til en prioritering af styrelsens kerneopgaver. Så skal toplederne også reelt i spil.

Men for at vende tilbage til spørgsmålet om, hvordan man sikrer, at travle topchefer bruger tid på mål- og resultatstyring? Det korte svar er vel, at det er en helt central del af det at være topleder. Det skulle det i hvert fald gerne være.

Der er blevet udgivet mange publikationer fra Finansministeriets side, siden konceptet blev introduceret forste gang, men hvad gor, at styringsredskabet denne gang bliver forankret og integreret lokalt?

Det er et helt rimeligt og godt spørgsmål, og om to eller tre år har vi et klart billede af, om det rent faktisk bliver tilfældet. Det, der gør, at vi trods alt er forsigtige optimister her, er, at vi fra Finansministeriets side i endnu højere grad tidligere har forsøgt at lave en grundig analyse af, hvad problemerne er, hvad de mulige løsninger kan være og en bred interessentinddragelse. Det forhold, at det endelige produkt har fået en særdeles positiv modtagelse, gør også, at vi er forsigtige optimister - altså optimistiske i forhold til at tro, at vi har en model nu, som alt andet lige kan blive mere styringsrelevant end de hidtidige resultatkontrakter.

Så hører det også med til historien, at der er mange ministerier, som allerede er rigtig godt på vej, og allerede gør nogle af de ting, som også ligger i den nye model. Om ministerierne så lige kalder det mål- og resultatplan, det er jo ikke noget, vi går op i. Vi går op i resultatet, vi går op i værdiskabelsen af den styring, der er. Og om man så kalder det en resultatkontrakt eller en mål- og resultatplan derude, det er ikke så vigtigt. Den nye model er jo ikke noget fuldstændigt revolutionerende brud med fortiden, men det er et forsøg på at sige, at nu prøver vi at gøre tingene på en lidt anden måde. Det er også derfor, vi har valgt det utrolig mundrette navn mål- og resultatplan i stedet for resultatkontrakt. 